\section{Life among stones and bones}

\section{Jacquetta Hawkes}

Disclosing the Past: An Autobiography.

By Mary Leakey.

Weidenfeld \& Nicolson/Doubleday:

1984. Pp. 215. £12.95, \$15.95.

THE Leakey family, Louis, Mary and their sons Richard and Jonathan, have between them done more to reveal the early ancestry of the human family than the rest of the scientific world put together - or so it seems. Working together and separately in Kenya, Tanzania and Ethiopia, they have unearthed a prodigious number of primate fossils from Miocene apes to early forms of Homo sapiens. At the same time they, and Mary in particular, have made an important contribution to our knowledge of the earliest tool forms and their evolution.

I cannot resist thinking of the Leakeys as a unit, yet this book is very much a personal autobiography, opening with chapters on Mary's childhood with its constant travel dictated by her much-loved painter father. She had no regular schooling and drove away unhappy governesses. Can there be any other person today who has never passed a single examination and yet is heaped with honorary degrees and exalted academic honours of all kinds?

Through her father, Mary was already seriously interested in archaeology when, in 1933, she met Louis and they were soon irresistibly in love. Their association, and Louis's abandonment of his wife, rocked Cambridge and echoed round the archaeological world: Mary tells the story fully and with honesty. In the long run this scandal may have been a boon to science, for it meant that Louis, already known for his discoveries in East Africa, got no further support from his college and so was led to settle with Mary in his native Kenya.

In the late 1930s and through the war years they were ceaselessly active in exploration and digging, all the time so desperately short of money that their lives were hard and their work was handicapped. Elspeth Huxley observed "they live on the smell of an oil rag"'. Yet during the war their great discoveries began outstanding among them Olorgesailie, where Acheulean handaxes lay massed on the ground like fallen apples, and the Miocene fossils of Rusinga Island in Lake Nyanza, where later Mary's extraordinarily sharp eye was to spot the first skull of Proconsul. Although this genus of ape has proved not to be a direct human ancestor, the find, made in 1948, was to lift Mary towards the heights of her independent career.

By this time Louis's staging of the First Pan-African Conference had brought African prehistory wide recognition and helped at last to attract sufficient funds for the Leakeys to make regular excavations at Olduvai, the great gorge that slices through two million years of Stone Age history. After several seasons there, in 1959 Mary made the discovery which, she says, marked the second turning point in her life after that of Proconsul. This was the skull Louis was soon to announce in Nature as Zinjanthropus, a new genus - which he subsequently had to accept as a robust australopithecine.

"Zinj", alias "Nutcracker Man", brought the Leakeys popular renown and ample funds from the National Geographical Society. Ironically, Zinj had in fact been a disappointment to Louis, since he had always longed to find an early Homo which would expose the australopithecines as an abortive sideline of evolution. He was therefore overjoyed when, within a year and slightly lower in the same stratum, Jonathan came upon a larger-brained, more-gracile hominid. $\mathrm{He}$ was immediately recognized as having made the tools hitherto attributed to Zinj, and presently Louis dared to name him, again in this journal, as Homo habilis. Readers will recall the subsequent

\section{Truth on the ground}

\section{Derek Ager}

\section{Memoirs of an Unrepentant Field}

Geologist: A Candid Profile of Some Geologists and Their Science 1921-1981. By F.J. Pettijohn.

University of Chicago Press: 1984. Pp. 260. \$25, £23.

As A regular reviewer, I admit that I do no always read every word of all the books that are sent to me. Life is short and literature is long; I hope I do no injustice by my judicious skipping. But with this book I can honestly say that I read every word and they were all fascinating.

From the title I expected a stout defence of field geology by one of its greatest protagonists, and I presume I was asked to review the book because of remarks I published recently to the same effect. In fact I drafted a tentative opening to this piece saying that I felt like the madam of a brothel being asked if I approved of sex. That still applies and is exemplified by Professor Pettijohn's cry "Why, oh why, can't geology be taught were geology is and not in the lecture hall?'". But although the title indicates the author's basic philosophy, the book is much more than that.

Francis Pettijohn was in at the birth of most of the great developments in geology this century, from geochemistry and isotopes to marine geology and basin analysis. In sedimentology he was truly the midwife and through the book we see the vigorous growth of that infant with its crucial importance to the rapidly expanding oil industry in the age of the motor-car. controversy, which continues yet.

Cautiously, Mary recognizes Homo habilis, but it is just because she regards wrangles about our ancestral tree as premature - and odious - that she has preferred stones to bones, concentrating her research on material culture. She is still working, and the detection, not so long ago, of human footprints proving beyond doubt that hominids were walking upright over three million years ago, is one of her greatest triumphs.

Disclosing the Past is artlessly though agreeably written, and follows a chronological progress on the course of which science mingles with family and domestic affairs; in particular, the amazing variety of pets that have always shared Mary's homes here occupy many of her pages. I should judge that this very personal, informal chronicle, by a cool observer of both herself and events, will prove a valuable source for future historians of East African archaeology.

Jacquetta Hawkes (Mrs J.B. Priestley) is an archaeologist and author of many books, among them Mortimer Wheeler: Adventurer in Archaeology (1982).

Of course those of us like Pettijohn, who resist the urge to leap into black boxes, are likely to be labelled as old-fashioned and reactionary. When the thin section was introduced to geology by that great man H.C. Sorby (one of the few British geologists mentioned here), there was a similar resistance to "looking at mountains under a microscope". But fortunately geologists continued to look at mountains just as they now check their satellite pictures with what is quaintly known as "ground truth". What Pettijohn is saying is that there is no other kind of truth. At the same time, like the first-rate geologist he is, Pettijohn makes use of all the tools that are available to him. Thus he was a pioneer in the use of the aerial magnetometer for mapping the Lake Superior ironstones (it had only previously been used for detecting submarines).

But we start from the world of a small Mid-Western town at the beginning of the century, with an unpaved main street lined with hitching posts; the heroic age of American exploration had just ended, with the last of the covered waggons and the great gold rushes. Pettijohn's parents were school teachers in Wisconsin. His father later moved into local university administration and then to the University of Minnesota where Pettijohn began his formal geological education. His distinguished career unfolded through a series of universities, from Minnesota to Berkeley, to Chicago and to Johns Hopkins (the last move largely because Chicago had incredibly abandoned field geology). Like many academic geologists in the United States, he also worked for the oil industry and for the US Geological Survey.

There is in the book more about geolo- 